\title{
Teaching English International Lingua Franca (ELF) in ASEAN Economic Community Context: Teachers and Students Perspectives
}

\author{
Idaryani Fidyati, Saifullah and Dini Rizki \\ Malikussaleh University, North Aceh, Indonesia
}

\begin{abstract}
Purpose - The purpose of this study is to find out the perspectives of students and English teachers on English Lingua Franca (ELF) at a tertiary level in one of the public universities in Lhokseumawe Municipality in Aceh and to find out the possibility of adopting the concept of teaching English as ELF to raise the students' awareness of their identity as part of the ASEAN Economic community and as a means of communication among the Community.

Design/Methodology/Approach - The research employs basic interpretive study by delivering questionnaires to 40 students from different disciplines and conducting interview to 6 English teachers from targeted research university in Lhokseumawe, Aceh, Indonesia.

Findings - The study addresses that the majority of the students are aware that English is no longer possessed by an inner circle of English users and realize the use of English as means of communication in globally context. However, the students do not understand the English as ILF. Besides, they do not enable to envisage themselves as part of the global community of English users as their identity. The research also indicates that majority the interviewed English teachers do not realize the concept of teaching ELF in the university.

Research Limitations/Implications - The findings of this research may shed light for other English teachers in Aceh to improve their teaching method in order to improve students' speaking skill and their awareness of their identity as a part of global imagined community of English users within the ASEAN Community Economic context.

Practical Implications - The solutions offered in the paper could improve the teaching method of English teachers particularly in Aceh, Indonesia.

Originality/Value - The research of students' and teachers' perspective of ELF in Lhokseumawe, Aceh, has not yet been published.
\end{abstract}

Keywords Students' identity, English Lingua Franca, Teaching-learning

All papers within this proceedings volume have been peer reviewed by the scientific committee of the Malikussaleh International Conference on Multidisciplinary Studies (MICoMS 2017).

(C) Idaryani Fidyati, Saifullah, DiniRizki. Published in the Emerald Reach Proceedings Series. Published by Emerald Publishing Limited. This article is published under the Creative Commons Attribution (CC BY 4.0) licence. Anyone may reproduce, distribute, translate and create derivative works of this article (for both commercial and non-commercial purposes), subject to full attribution to the original publication and authors. The full terms of this licence may be seen at http:// creativecommons.org/licences/by/4.0/legalcode

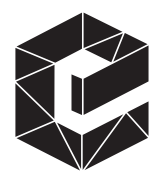




\section{Proceedings of 1. Introduction}

MICoMS 2017 English is learnt by students in Indonesia as a foreign language after Bahasa Indonesia as their first language in line with (Baker, 2011) statement that English does not have official status in many expanding circles. Since Indonesia is one of the expanding circles according to Kachru's classification as cited in Harmer (2007), Indonesia students face difficulty in mastering English particularly in term of speaking. It is due to the lack of opportunity and less contact of the students to the use of English in the students' daily basis.

Furthermore, within an examination-dominated learning context in Indonesia, many teachers face problematic situations in teaching English language because of some prominent issues such as identity and motivation. However, English teachers have important role in teaching their students since the way of their teaching can determine whether the learner will engage or not during learning process. Lamb (2009) on his study of two Indonesian learners finds out that one of his research participants considered that he has to learn English not because of his willingness to learn it but he ought to learn it because of obligation. Lamb also finds that his another participant felt reluctant to engage during learning process because of the way of teaching of her teacher.

Moreover, teachers who play a key role in classroom should be aware that teaching English involves students' identity which then can lead the students to invest their time and their effort in learning and using English language. In line with this, Norton (1995) states that the identity relates to the position of learners toward culturally and historically constructed social life and the latter's interaction with target language interlocutor. Thus, the L2 teachers should be more aware the strategies used to support the students in accomplishing better results in second language (L2) learning.

The trend phenomena of ASEAN Economic Community (hereafter AEC) may lead to the need of $\mathrm{AEC}$ who share various linguistic and cultural backgrounds to communicate using English as ASEAN lingua franca. The research is conducted in one of Public Universities located in Lhokseumawe, Aceh, Indonesia.

\section{Literature review}

\subsection{The differences between world of englishes (WE) and english as lingua franca (ELF)}

English as international lingua franca is applied when English is used as means of communication among the native speakers (NSs) other than English rather than exclusively with the NSs. Furthermore, Kirkpatrick (2011) and Firth (1996, as cited in Kirkpatrict 2011) mention that ELF is also defined as the people who use English which do not share the same mother tongues and are culturally influenced free and they use English language merely as means of communication. Further, House (2012) describes that English lingua franca as transnational communicative language is essential in negotiability and variability of proficiency and the openness to the integration of language forms of NSs other than English. House mentions that ELF is transactional language for communicative purpose and advantage of a particular community without claiming as marking identity of specific community. Therefore, it can be summarized the differences between WE and ELF from Kirkpatrick work as follows:

First, on the one hand, WE is found in the distinctive varieties on the use of pronunciation features which are derived from different Englishes such as American English, Indian English, or African English, on the other hand, ELF shares the different pronunciations when people from different native languages speak English together. Second, the difference is in term of using vocabulary where WE uses specific vocabulary with culturally influenced in order to be able to describe about local issues. The users of WE generally borrow the local language to express their local phenomena such as Australian 
English uses words Kangaroo and Kuala to exemplify the origin animals of Australia. In addition, WE use culturally specific lexical items to be able to describe particular words from varieties of sources in order to translate local word or idiom. This is very common in WE that can alter the meaning of words from Standard English vocabularies or idioms because the WE users try to translate local words or local idioms into English. However, in ELF, this is not expected to happen. As Seidlhofer (2006, as cited in Kirkpatrict, 2010) has postulated that in ELF, the speakers should avoid the unilateral idiomaticity in order to eliminate misunderstand within ELF communication context. Third, WE is characterized with the use of code-mixing that happen due to the speakers of world of English are multilinguals, learning English as Foreign language or second language, and share the same linguistic background. However, code-mixing will not happen in using ELF since the speakers of English lingua franca are from different linguistic backgrounds. Furthermore, Kirkpatrict (2008, as cited in Kirkpatrict, 2010) states that the users of English Lingua Franca (ELF) does not intend to show the speakers identity but more focus on successful communication. In contrary, WE is characterized by speakers' expressions which reflect their local cultural norms and pragmatic norm as part of their identity.

Furthermore, according to Canagarajah (2006), WE has been unsuccessful to accommodate the difficulty of global English. All NSs are outnumbered by non-native speakers (NNs) with multilingual background and the use of English in expanding circle exceeded the number of English users in the inner circles. Seidlhofer (2004, as cited in Canagarajah, 2006) concludes that the pragmatic strategies that have been identified in ELF research are when misunderstandings occur, the ELF speakers tend to resolve it either by topic change or over negotiation using communication strategies such as rephrasing and repetition. As long as a certain threshold of understanding is obtained, interlocutors seem to adopt of Firth (1996, as cited in Canagarajah, 2006) term the "let it pass principle," that gives the impression of ELF talk being overtly consensus-oriented, and respective, mutually supportive.

Moreover, Canagarajah believes that ELF assists the effective communication with safe talk, and constructs solidarity when gap or mistakes occur. Furthermore, Snow et al. (2006) add that usually NNs use English as the mixtures of NSs and NNSs. Thus, it is essential to prioritize a variety of English in speaking and learning which is understood and respected by both NSs and NNs and suggest to adapt the ELF norms when the speakers are communicating within ELF interaction context without justifying on how the NNSs communicate but rather than the users are looking for the common ground that both NNSs and NSs will negotiate in order to attain an effective communication.

\subsection{ELF in ASEAN context}

ASEAN shorten from Association of South East Asian Nations which consists of 10 nations: Indonesia, Malaysia, Myanmar, Vietnam, Brunei, Thailand, Laos, Cambodia, Singapore, and the Philippines. The phenomena of ASEAN Economic Community (AEC) will accelerate the growth of international contacts among the people in ASEAN region. English will be predominance language used as means of communication which may lead intensively the use of English among ASEAN countries who share different linguistic and cultural backgrounds. It means that the English is used as transnational language among people in ASEAN region. Based on the ASEAN Charter in ASEAN Summit in November 2007, the article 34, stated in term of working or official language, that the language as means of communication among ASEAN countries is English (Kirkpatrick, 2008, 2011).
Teaching English International Lingua Franca (ELF) 


\section{Proceedings of 3. Methodology and research design}

MICoMS 2017 The study employs basic interpretive study by conducting semi-structured interviewing to six English teachers and 40 students in order to gather in depth information on the students' and English teachers' perspectives of ELF and the teaching method that English teachers are currently used in teaching English. The questionnaires were delivered for 40 students from different faculties with different experience in learning English.

\section{0}

\subsection{The population and sample}

The research participants were students from different economic, law, engineering, and social sciences and English teachers from different faculties of the targeted university for this research in Lhokseumawe, Aceh, Indonesia. The six teachers teach English in each of the following disciplines: Economics, Agriculture, Engineering, and Political and Social Science and students. Moreover, of 40 students, 30 students are the first year students from Law Faculty, 5 students are from the third years students also from faculty of Law and are joining English course while the questionnaires were delivered. The rests were the fourth year students from different faculties other than Law Faculty and are very active in participating English debate competition program. Also, from total 40 students, some students were from outside of Lhokseumawe, Aceh, such as from West Sumatera and North Sumatera.

\section{Results}

\subsection{Students' responses}

The table demonstrates the responses of questionnaires delivered to the students Table 1.

The data above show that all students agree that English is an important subject to learns and majority of students said that their aim to learn English is to improve their English ability. However, the majority of the students consider that the meeting session offered at the university is not sufficient for the students to improve their English ability. Furthermore, almost all students believe that English no longer belong to inner circle of English users. Although many of the students still believe that the students have to learn the

\begin{tabular}{|c|c|c|c|}
\hline \multirow[b]{2}{*}{ No. } & \multirow[b]{2}{*}{ Questionnaires } & \multicolumn{2}{|c|}{ Responses } \\
\hline & & Yes & No \\
\hline 1. & Is English important subject to learn? & 40 & \\
\hline 2. & Do you learn English to improve your English ability? & 37 & No \\
\hline 3. & $\begin{array}{l}\text { Does the meeting session so far in classroom is enough to improve your } \\
\text { English skill? }\end{array}$ & 7 & 33 \\
\hline 4. & $\begin{array}{l}\text { Is English only possessed by certain countries such as United Kingdom or } \\
\text { United States of America? }\end{array}$ & 18 & 28 \\
\hline 5. & Are the majority of English users from inner circle users? & 16 & 26 \\
\hline 6. & $\begin{array}{l}\text { Is English only for particular learners such as the students of English } \\
\text { Department? }\end{array}$ & 2 & 38 \\
\hline 7. & Does someone have to speak English in Native speaker accent-like? & 30 & 10 \\
\hline 8. & $\begin{array}{l}\text { Do you use social media such as Facebook or Twitter to speak with } \\
\text { English } \\
\text { speaker outside of Indonesia? }\end{array}$ & 23 & 17 \\
\hline 9. & Should you also learn about the culture of Native speakers? & 31 & 9 \\
\hline 10. & $\begin{array}{l}\text { Is English the only international means of communication at international } \\
\text { level? }\end{array}$ & 33 & 7 \\
\hline
\end{tabular}


culture of the inner circle users, more than half of the participant are aware that the majority of English users are not from inner circle and majority of the students consider that English is the only international means of communication and should be learnt by all students.

\subsection{English teachers' responses}

The questions delivered to the English teachers when the interview was conducted are shown in Table 2.

Based on the interview, it indicates that from six teachers, one English teacher applied the ELF teaching concept; however, three teachers did not understand or once heard about ELF. The rest of English teachers once heard about ELF but did not give clear definition or clarify of what ELF is. All English teachers agree that internet with smooth connection is essential for teaching-learning process. They also agree that supporting tools such as infocus and internet with smooth connection is prominent tool in teaching. One teacher mentions that enough preparation became one of important thing factor that helped the teacher in teaching-learning proses. All teachers agree that the engagement of students was the significant challenge for the teachers during teaching-learning. Furthermore, good strategies are also considered to be significant in order to gain students engagement.

\section{Discussion}

\subsection{Students'perspective}

The table presents that all students believe that English is an essential language to learn for all learners at tertiary level. In addition, the students realized that the meeting session offered at the University is not sufficient to improve their English ability. In line with this, Matsuda (2003a, 2005, as cited in Snow et al., 2006) postulates the curriculum that integrates the teaching material that represents the varieties of WE and enable students to be exposed to English speakers from various backgrounds which focus on communicative effectiveness rather than grammatical accuracy based on inner circle expectations. Further, another finding is that majority of the students were already aware that English language is no longer possessed by the inner circle of English users which indicates that the students realized that English is spoken and used widely by global imagined community outside of the inner circle users. The awareness of the students of using English majority are not from inner circle, indicates the students are aware that English is also spoken as means of communication from different linguistic background including in ASEAN region since most of the students realize that English is the only language as international means of communication.

However, they are not able to envisage themselves and realize their identity as a part of global imagined community of English users since the students still consider that English as a foreign language instead of English as international lingua franca. When English is learnt

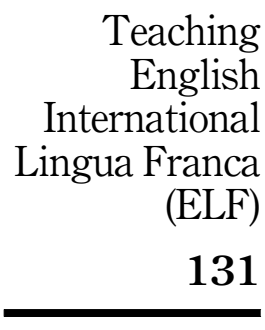

Teaching English International (ELF) 131

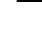

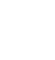


Proceedings of MICoMS 2017 as a foreign language, the students will be motivated to learn the language due to the curiosity of the culture of the target language. The students will envisage themselves to meet the inner circle of English speakers. Within Indonesian context, particularly in Lhokseumawe context, the small municipality which consists of Acehnese people as majority population, it will be rare occasion for the students to meet and practice English with people from inner circle countries. However, if the students realize about their identity as part of globally English users, the students will not be bothered by the culture of the speakers from inner circle when learning English.

Takahashi (2014) proposes the new method to English Language Teaching (ELT) which enables the learners to communicate effectively both with NSs and NNs within ELF context. The intelligibility issue has to be main concern rather than attaining native-like accuracy (Graddol, 2006, as cited in Takashi, 2014). Takashi also suggests that in teaching, the students have to be exposed to varieties of English. Thus, the ELF teaching concept can raise the awareness of the students of different ways of speaking English, language variability and change and not to be justified by particular speakers from inner circle.

\subsection{Teachers' perspectives}

The result of this research revealed that only one from six English teachers were aware of the concept teaching ELF and try to implement it in teaching English. Two other teachers once heard about the ELF but are not able to elaborate ELF and the rest of three teachers do not even once heard about ELF. This result shows that most of English teachers do not understand appropriately the term of ELF and the teaching concept of English lingua franca. So far, majority of English teachers teach English as Foreign Language (EFL) or WE and most of them are not concerned or aware of teaching ELF to the students.

However, Prodomou (2007) challenges the notion of ELF users can exclude the present of NSs meaning it excludes the inner circle users and if using ELF due to the reason of NNs has outnumbered of NSs, he claims that the concept of ELF has concealed 380 millions of NSs that he argues as dismissive attitude toward NSs. However, it is considered that Prodomou's concern is exaggerated since as mentioned earlier by Nickerson (2015) that NSs as inner circles of English users are still recognized as accountable communicator but not as ideal communicator within ELF interaction context.

When English is taught as foreign language, the students will envisage themselves to meet the inner circle speakers in order to get themselves to be motivated in speaking English. Within Indonesian students, it will be challenging for the learners who does not have interest to travel around the world, on the other hand, ELF teaching concept will enable the earners to envisage themselves as part of globally English users without travelling abroad.

Therefore, the particular designed website or social media such as Facebook, Twitter other on-line programs is suggested to be adopted to develop speaking assignment which will enable the students to have contact and use English from outside of Aceh virtually. It is suggested that the university has to ensure the availability of smooth Internet connection to support the English teachers in finding teaching resources for ELF and create the particular assignment relating to the ELF teaching concept. The ELF teaching concept requires the smooth internet connection in order to develop and design the specific syllabus for teaching resources. Furthermore, the teaching resources have to be developed by modifying the speakers from 10 ASEAN countries to demonstrate the zero geographical barriers in using English to the students, which will eliminate the issues of the absence of actual interlocutors of English users in Lhokseumawe, Aceh. Constructing successful communication by 
adopting rephrasing and repetition strategies or the "let it pass" strategies also should be taught to the students.

\section{Conclusion}

The concept of teaching of ELF should be figured out English teachers according to student needs, as students do not realize their identity as part of an imagined global community of English users. Teaching ELF is fruitful to be implemented at the university, Lhokseumawe, Aceh. Thus the implementation of ELF teaching concept will help both of teachers and learners to overcome the absence of NSs speakers in improving speaking ability of the students. However, further research is needed to find out the appropriate ELF focused curriculum to be implemented in Aceh to enhance students' English ability at the tertiary level.

\section{References}

Baker, C. (2011). Foundations of Bilingual Education and Bilingualism (5th ed.). Multilingual Matters, Bristol, UK (Chapter 1).

Canagarajah, S. (2006). "Negotiating The Local in English as A Lingua Franca". Annual Review of Applied Linguistics. Vol. 26, pp. 197-218. 0267-1905/06 \$12.00.

Dornyei, Z. (2003). (Ed). Attitudes, Orientations, and Motivation in Language Learning: Advances in Theory, Research, and Application. Blackwell, Oxford, pp. 3-32.

House, J. (2012). "English as a Global Lingua Franca: A Threat to Multilingual Communication and Translation?”. pp. 363-376. https://doi.org/10.1017/S0261444812000043.

Harmer, J. (2007). Teaching Language Skills. The Practice of English Language Teaching (4 ${ }^{\text {th }}$ ed.). Pearson Education, Harlow.

Kirkpatrick, A. (2008). "English as the Official Working Language of the Association of Southeast Asian Nations (ASEAN)”. English Today, Vol. 24, No. 2, pp. 27-35.

Kirkpatrick, A. (2011). "Plenary Speeches English as an Asian Lingua Franca and the Multilingual Model of ELT" (pp. 212-224). Available: https://doi.org/10.1017/S0261444810000145 [accessed December 2009].

Lamb, M. (2009). Situating the L2 Self: Two Indonesian school learners of English. In Dornyei \& Ushioda (Eds), Motivation, language identity and the L2 self (pp. 229-245). Multiligual Matters: Bristol, UK.

Nickerson, C. \& B. Planken (2009). Europe: The state of the field. In F. Bargiela-Chiappini (ed.), The handbook of business discourse. Edinburgh: Edinburgh University Press, 18-29.

Norton, B. (1995). Social identity, investment, and language learning. Tesol quarterly, Vol. 2, 9-31. Retrieved from Deakin University database.

Prodomou, L. (2007). Is ELF a variety of English?. English Today 90, Vol. 23, No. 2, Cambridge University Press; United Kingdom, DOI: 10.1017/S0266078407002088.

Snow, M.A., Kamhi-stein, L.D. and Brinton, D.M. (2006). Teacher Training For English As A Lingua Franca. Annual Review of Applied Linguistics, Cambridge University Press; United Kingdom., 261-281.

Takahashi, R. (2014). “An Analysis of ELF-Oriented Features in ELT Course Books”. English Today. Available: https://doi.org/10.1017/S0266078413000539.

\section{Corresponding author}

Idaryani can be contacted at idaryani@unimal.ac.id
Teaching

English

International

Lingua Franca

(ELF)

133

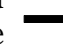

